Journal of Social Sciences 7 (1): 6-12, 2011

ISSN 1549-3652

(C) 2010 Science Publications

\title{
Integrating Sustainability into Teaching and Research at the University of the South Pacific to Enhance Capacity for the Sustainable Development of Pacific Island Countries
}

\author{
${ }^{1}$ Kanayathu C. Koshy, ${ }^{1}$ Aliti Koroi, ${ }^{2}$ Neil Netaf and ${ }^{2}$ Cresantia Koya-Vaka’uta \\ ${ }^{1}$ Centre for Global Sustainability Studies, \\ University Sains Malaysia, 11800 USM, Penang, Malaysia \\ ${ }^{2}$ The University of the South Pacific, Box 1168, Suva, Fiji Islands
}

\begin{abstract}
Problem statement: Pacific Island countries have been recognised globally as a 'special case for environment and Sustainable Development (SD)' because of their extreme vulnerability to a host of both external and internal development challenges such as: Narrow range of resources, high population density, limited export volume, impacts of climate change and natural disasters, trade, ICT and globalisation pressures. As part of their strategic approach to address these threats, the island countries have become party to a number of international and regional multi-lateral agreements. However, there are severe capacity constraints, at all levels-individual, institutional and systemic-to the full-scale implementation of these agreements. Part of the problem is that the educational system in general and in particular the higher educational institutions have not yet mainstreamed sustainability into their curriculum. Thus there is a 'campus-workplace' mismatch for SD implementation that needs to be addressed urgently. Approach: This study addresses how the University of the South Pacific (USP) and two other Pacific universities in the Pacific island region have been addressing these capacity issues using a 'logical framework approach' for the development and implementation of two on-going, multidisciplinary ESD projects. The first is a USP project, funded by the Asia-Pacific Cultural Centre for UNESCO (ACCU-USP), the second may be seen as a much broader extension of the ACCU-USP project, in the form of a networked initiative involving USP, UPNG and NUS. Results: Within the limitations discussed elsewhere (ibid), the ACCU-USP and EDULINK-NIU (NIU: network of island universities) projects are progressing well in establishing institutional structures for the promotion of ESD, developing new courses and resource materials, establishing new postgraduate programmes, enhancing community capacity to manage natural resources sustainably and contributing substantially to regional integration. In addition, these projects play a key role in the promotion of the Pacific ESD Framework (2006) and the Pacific ESD Action Plan (2007), both endorsed by the Pacific Education Ministers. Conclusion: The ACCU-USP and EDULINK-NIU projects attempt to strike a balance between the need for SD capacity building to be multidisciplinary and problem oriented by design and maintaining the status quo that favors discipline based structuring of knowledge creation and dissemination. While the renewed commitment of USP, UPNG and NUS to reorient their curriculum, research and outreaches to meet the sustainability capacity needs is beginning to bear fruit, the lack of long-term funding and the low level of awareness on sustainability may hamper progress.
\end{abstract}

Key words: Education for Sustainable Development (ESD), Johannesburg Plan of Implementation, Sustainable Development (SD), Mauritius Strategy (MS), Environmental Impact Assessment, community engagement, Community empowerment, educational system, socio-cultural, economic challenges, Logical Framework Analysis, Small Island Developing States

\section{INTRODUCTION}

Recognizing that the roles of universities everywhere are changing rapidly in a world that faces several sustainability challenges, the University of the South Pacific (USP) has embraced 'Education for
Sustainable Development' (ESD) as a major guiding principle for its journey forward. The establishment of the Pacific Centre for Environment and Sustainable Development (PACE-SD) in 2001 had a major catalytic effect on USP's efforts to focus on educational approaches that build regional capacity for the

Corresponding Author: Kanayathu C Koshy, Centre for Global Sustainability Studies, University Sains Malaysia, 1

1800 USM, Penang, Malaysia 
implementation Sustainable Development (SD). In this paper we discuss the context, methodology and outputs of two major ESD projects-UNESCO-ACCU-and EDULINK supported and implemented by USP. One of them, EDULINK-NIU, is a partnership initiative with the University of Papua New Guinea (UPNG) and the National University of Samoa (NUS) in the Pacific. The implementation if these projects is also an example of the contribution higher education institutions can make towards the implementation of the Pacific ESD Framework (Framework, 2006, http://unesdoc.unesco. org/images/0014/001476/ 147621e.pdf) and the Pacific ESD Action Plan (Action Plan, 2007, http://www. usp.ac.fj/pace/esd).

Background: The Pacific Island Countries (PICs) are fully aware of the global environmental, socio-cultural and economic challenges that underpin sustainable development. Many of the PICs, comprising the island nations of Micronesia, Melanesia and Polynesia, have already been badly affected by these externalities to development.

PICs and their sustainability challenges: The general characteristics and development challenges of PICs may be summarised as: (i) internal: traditional cultures, local knowledge and management systems (IKS), consensus approach, subsistence living, narrow range of resources, fragile ecosystems and economies, high population density, low technology, communication and transport handicaps and poverty and (ii) external: climate change, globalization, trade liberalization, HIV/AIDS, security and ICT. A somewhat similar analysis of the environmental challenges returns the following: (i) natural: ENSO related droughts/floods, cyclone related floods, tsunamis, sea surges, earthquakes, landslides and, (ii) anthropogenic: waste, extractive technologies, soil erosion and coastal issues. The combined effect of these makes PICs a special case for environment and development (Koshy et al., 2008).

In recognition of this extremely alarming situation, the region and the individual island countries have made a strong commitment to international efforts to prevent further irreversible environmental change and to promote sustainable development by becoming party to a number of Multi-lateral Environmental Agreements (MEAs). Important among them are the Rio Conventions and Agenda 21, Barbados Program of Action (BPOA), Johannesburg Plan of Implementation (JPOI, WSSD) and the Mauritius Strategy (MS) for the further implementation of BPOA-all of which emphasise the need for development to be more sustainable, particularly in island nations with limited natural resources and skill base (Koshy et al., 2008). The implications of the above for the implementation of sustainable development are huge.
UNDESD and the pacific: With the realization that the PICs have to move beyond compliance to commitment in implementing ESD as part of the UN Decade of Education for Sustainable Development, the Pacific Islands Forum Education Ministers endorsed the Pacific Education for Sustainable Development Framework and a Pacific ESD Action Plan as an overarching mechanism to promote regional integration and sustainable development through education as envisaged in the Pacific Plan (www.forumsec.org.fj/pacific_plan), which is the blueprint for sustainable development of PICs. Several key stakeholders in the region, such as Ministries of Education, members of the Council of Regional Organizations of the Pacific, especially USP, the Secretariat of the Pacific Regional Environmental Programme and the Forum Secretariat, UNESCO Apia, NGOs such as Live and Learn, FSPI and WWF and the UNESCO national commission of New Zealand and Australia are involved in the implementation of the ESD action plan, the development of which was coordinated by PACE-SD/USP.

UNDESD and USP: Among the innovative outcomes of the World Summit on Sustainable Development were the 14 Type II voluntary initiatives, in addition to the Ministerial Declaration and the Johannesburg Plan of Implementation. As part of this, the Prime Minister of Fiji, on behalf of PICs, launched 14 Type IIs at WSSD, one of which was on 'Education based capacity building for sustainable development', led by USPPACE/SD and SPREP. While USP's interest was on formal education and research based activities, SPREP focused more on non-formal and informal approaches. Both parties were committed to policy interactions necessary for the implementation of this initiative. With the launching of the Decade of Education for Sustainable development by UN (UNDESD 2005), there has been a revival of Pacific ESD, (http://www.desd.org/desdcd/asiapacific.html). Within the Type II commitments and USP's long-standing focus on sustainable pacific development, the university took the initiative, along with University of the West Indies, University of Malta, University of Mauritius and the University of US Virgin Islands, to establish a University Consortium of Small Island Sates (UC-SIS) for networked capacity building across SIDS (Small Island Developing States). The UC-SIS was launched officially during the international meeting of SIDS at Mauritius, January 2005. At the same time, SPREP revamped its on-going activities under environmental education to conform more to ESD principles and practices. 
Based on the critical role USP has been playing in the pacific region's human resource development, which is an important pre-condition for sustainable national development, USP was awarded the Regional Centre of Expertise (RCE) status for ESD by UNU-IAS (UN University-Institute for Advanced Studies) in 2005 and the Centre of Excellence (COE) award by ACCU/ UNESCO in 2006. While USP was one of the first 7 foundation RCE's in 2005, the numbers has now risen to 74 with RCEs spreading across the world. The fact that USP was one of the only 5 COEs across Asia Pacific makes the University unique in its ESD commitments and capacity.

These achievements also meant that USP has on its shoulders a greater responsibility to live up to the promises it made, particularly during the WSSD Plenary and the level of expectations generated. Based on the decisions of a day-long ESD Colloquium in Nov 2005, USP moved forward strategically to implement various activities in the area of teaching, research and community engagement-the triple bottom mission areas of universities in general. The institutional arrangements needed to manage the change towards the new ESD paradigm was understood to be the administrative structures that create the enabling environment to 'make things happen'.

Problem statement: Given the above sustainability scenario in the pacific region, we used the Logical Framework Analysis (Approach), LFA, to develop a 'Problem Tree', Fig. 1a, to identify the research problem and their hierarchical order for further involvement. Lack of SD/ESD leadership was identified as the highest level problem which is the result of low SD/ESD capacity and opportunities for training in the region. These problems manifest in different ways in the universities of the region. The lower operational level problems which lend themselves to university engagement are shown at the bottom of the diagram.

Following the LFA guideline a corresponding 'Objectives Tree' was developed, Fig. $1 \mathrm{~b}$. Consideration of the 'action' required to progress from the problem phase to the objective (solutions) phase resulted in a variety of project level activities in the areas of ESD administration and institution building, curriculum changes, targeted action research and community empowering for the overall implementation of sustainability in the region.

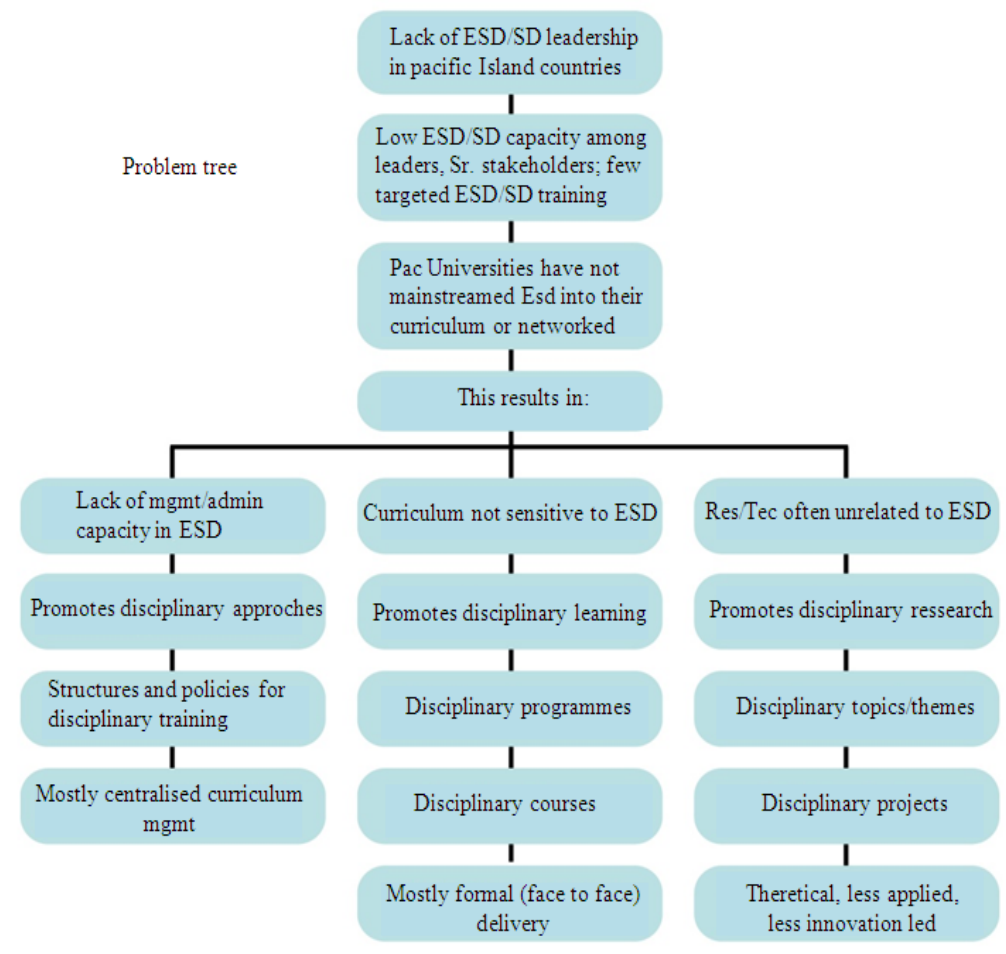

Fig. 1a: Generic ‘Problem Tree’ for the ACCU and EDULINK-NIU projects 


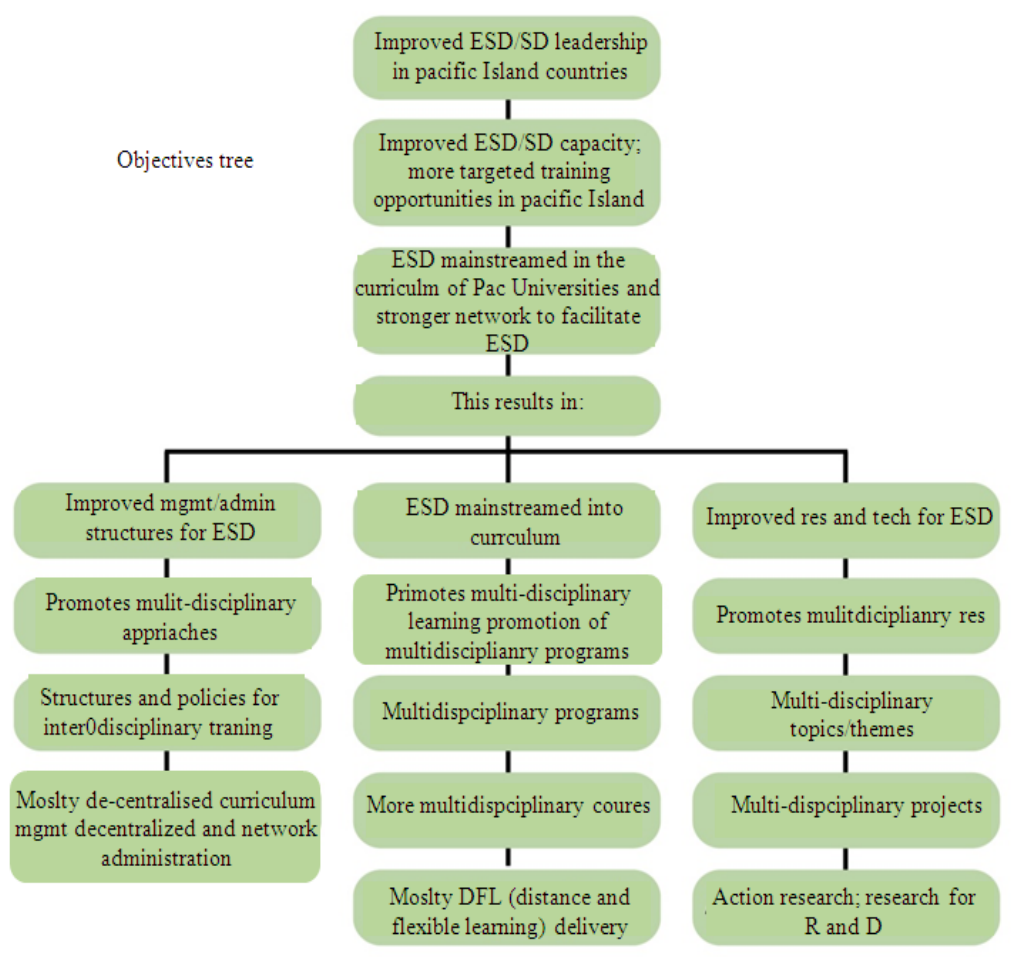

Fig. 1b: Generic 'Problem Tree' for the ACCU and EDULINK-NIU projects

\section{MATERIALS AND METHODS}

In both the ACCU-USP and the EDULINK-NIU projects, an integrated approach that involved the triple bottom line of SD and the triple bottom mission of higher education, ESD, was adopted as the foundation for action. Globally, SD is perceived as a paradigm shift, which is aimed at ensuring economic growth within the carrying capacity of the environment in a socially equitable and economically acceptable way.

Three interlocking circles representing economy, environment and society are usually used to explain this model with the overlapping centre showing the magnitude of development that is sustainable. A similar Venn diagram may be used to represent the three mission pillars of higher education, with teaching, research and community engagement representing the three circles where the overlapping centre being a measure of the sustainability mainstreaming at the institutional level (Fig. 2). The rectangle in the middle is used to list the specific sustainability focal areas, selected by USM and the partner universities.

\section{Application of the method:}

ESD projects at USP: Based on the outcomes of several levels of discussion, the ESD colloquium, the commitments in the Education Type II initiative and the international ESD recognition of USP, the university is currently implementing two major ESD projects.

The UNESCO-ACCU project: This is a Flagship ESD Project, funded by ACCU, Japan, 2006, which has three important components: (i) Teacher education, which includes teacher capacity building from basic to tertiary levels; indigenous education and development; pacific arts and culture, (ii) Sustainability education, this comprises: postgraduate diploma in sustainable islands and oceans development; diploma in environmental sciences, new master of law and, ESD resource material development and, (iii) Community empowerment, this includes the following projectscertificate in youth leadership; environmental stewardship for young people; certificate in community eco-tourism; village environmental rangers; media training and sustainable livelihood training (Koshy et al., 2009). The emphases within the three components are on formal training using ESD infused new and reoriented curricula offered via the distance and flexible mode, preparation of training materials for university students/teachers and, nonformal approaches aimed at village communities and other stakeholders. 


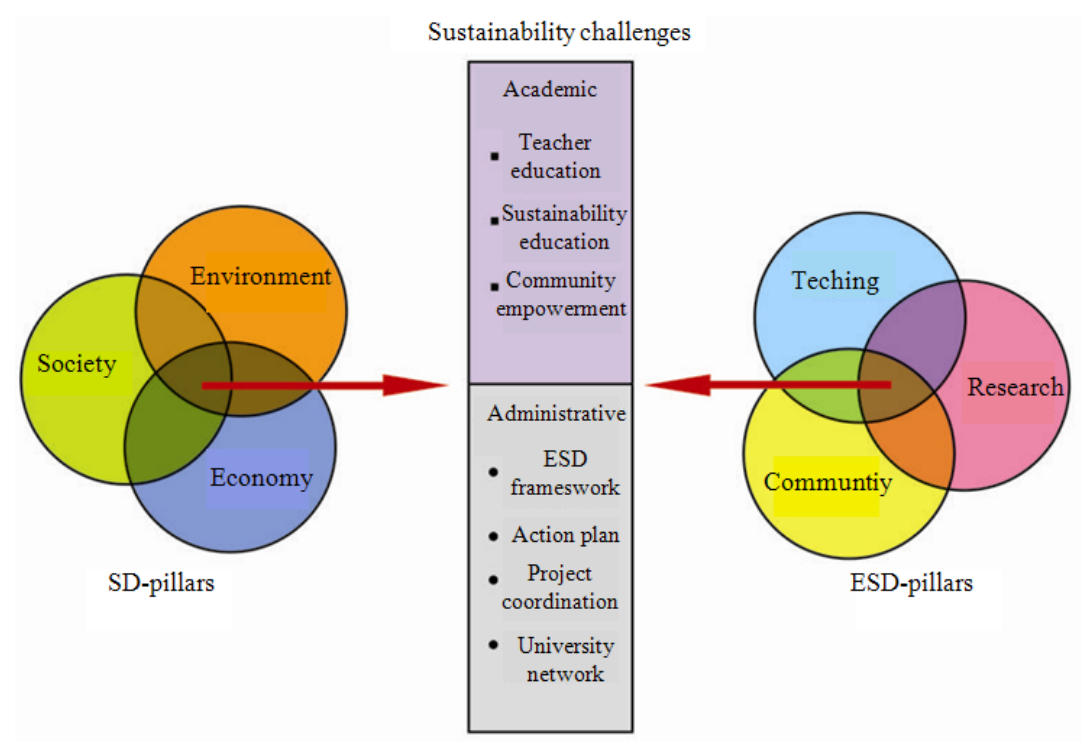

Fig. 2: An integrated approach to mainstreaming sustainability in the ACCU and EDULINK projects (Koshy and Corcoran, 2010)

EDULINK-NIU project: This project on 'Networking Island Universities for Mainstreaming ESD into Curriculum and Research' started in 2008, with funding support from the EDULINK program of the European Union. This is a novel and innovative move in the Pacific to link three major universities into an ESD Network to address the capacity and leadership challenges for sustainability training in the region. The NIU project, in addition to its ACCU-like objectives, focuses, in addition, on sustainability research and administrative/management arrangements necessary for the integration of ESD into the partner universities. The project has 4 major components as follows: (i) Administration and management (Board, Advisory committee, Project leader, Coordinators) (ii) Academic programme development and delivery (Teacher education, Sustainability education, Community empowerment), (iii) Research and technology (these are action research projects to complement component ii above and includes integrated waste management, (Rahman et al., 2010) ESD leadership training, Sustainable rural development (Eldrandaly, 2009) for poverty alleviation, Climate and extreme events as research themes). Under each of the three components, there are thematic areas and projects relevant to the different disciplinary divisions and the universities in the network.

\section{RESULTS AND DISCUSSION}

Combined ACCU-USP and EDULINK-NIU achievements: The necessity for team work within the inter-, multi and trans-disciplinary environment of ESD implementation in universities will also mean that progress, especially in the early stages, could be very slow. The Pacific experience is nothing different.

Within these limitations, USP and its partners have made considerable progress in the implementation of the two projects so far. Some of the important achievements are highlighted below:

- ESD Forum for Pacific Educators: A regional Forum, held in Fiji, March 2010, reviewed national curriculum needs, new initiatives in the Pacific for ESD mainstreaming and the future direction of these initiatives and agreed on a set of priority activities

- Book Launch: 'Education for Sustainable Development in the Pacific' (3-volume series): Volume 1: Continuity and Survival in the Pacificpresents a selection of articles by Pacific scholars exploring the ways in which Pacific societies live the principles of ESD, Volume 2: Pacific Stories of Sustainable Living-includes stories of Sustainable Living presented through the arts-including visual arts, poetry, chants, stories, dance and life stories; Volume 3: An Annotated Bibliography-a collection of abstracts and bibliographical information on ESD in the Pacific

- Postgraduate (PG) and Undergraduate (UG) Courses: (a) PG, (EV 414)-Climate Change: Impacts, Vulnerability and Adaptation, (b) PG, (EV425)-Environmental Impact Assessment and 
Strategic Environmental Assessment, (c) UG, Certificate in Eco-Tourism, (d) UG, Village Environmental Rangers Programme (VERP)Training Manual and stakeholder training (e) UG, Youth Environmental Stewardship and Leadership for Young People (YESP). In comparison, research projects have been rather slow in starting while a lot of background work is progressing. However, the encouraging development is that for the first time, ESD mainstreaming is happening under a robust administrative umbrella, which includes an overall Principal investigator for the new projects, institutional and sub divisional coordinators and a High-level ESD Advisory Committee

Initiatives within the pacific ESD framework and action plan: The main goal of the Pacific ESD framework is to empower Pacific peoples through all forms of locally relevant and culturally appropriate education and learning to make decisions and to take action to promote sustainability. To meet current and future social, cultural, environmental and economic needs and aspirations in a sustainable manner, three major priority areas have been identified in the Framework: (i) Formal education and training, (ii) Community based educations and (iii) Policy and innovation. The Framework also provides a monitoring matrix to assess progress in its implementation.

At the operational level, a major Framework would need an Action Plan for implementation. The Pacific ESD Action Plan was designed to meet this need. This Action Plan was based mainly on the Pacific ESD Framework while at the same time complementing other regional and international initiatives, particularly the Millennium Development Goals, the Forum Basic education Action Plan, Education for all, the UN Decade for Literacy, the SPREP Education and Communication Guiding Framework and the Pacific Youth Strategy. The Action Plan, which was developed by a regional ESD Working Group, coordinated by PACE-SD USP, made use of the results of an extensive regional mapping of ESD initiatives and identified specific objectives, activities and sub-activities in the following areas: Formal education, Non-formal education, ESD Governance, Research, knowledge and innovation and Communication and advocacy.

As is usually the case, an Action Plan is only as good as the implementation initiatives it generates. This is where the Pacific Universities, as individual institutions and as a network have risen to the task and made a difference in translating the action items into education-based activities. From experience, when universities engage in this fashion, there is a much higher chance of capacity building initiatives becoming more sustainable.

\section{CONCLUSION}

Those involved in ESD mainstreaming in universities would agree that it is hard to find something more multi-and transdisciplinary than sustainable development. It is also quite clear that the traditional discipline-based structuring of knowledge and research are here to stay. This combination constitutes a major challenge for the universities when implementing learning for sustainable development in higher education (Sterling, 2004).

Therefore, there must be major drivers at all levels (Gough and Scott, 2008 and articles therein) to move ESD forward. ESDs origin may be traced back to the UN Earth Summit at Rio and Agenda 21 (United Nations, 1992). BPOA, WSSD, Mauritius (MS), RCE, EU's EDULINK, ACCU-COE and UC-SIS represent only a portion of the different driving forces operating at the global level for ESD implementation. These initiatives catalyse the activities of educational ministries, universities, NGOs and a host of other stakeholders. The challenge is to translate them into action at the regional and institutional level. In the Pacific region, the role played by the Pacific Plan, Pacific Regional ESD Framework, Pacific Regional ESD Action Plan, Network of Island Universities (NIU), RCE (Pacific) and COE Pacific cannot be overemphasized as the major drivers. However, considering the magnitude of the tasks and responsibilities involved, sustaining the momentum will be a major challenge.

Despite all the drivers above, there are also significant barriers in terms of staff awareness, expertise, apathy, lethargy and institutional commitments to further progress the sustainability embedding process. In most universities, institutional structures favor status quo and there is substantial inertia towards external drivers. Thus, there is a period during which each institution and its faculty goes through a soul searching and priority setting before setting its long-term ESD vision against the needs of the communities they serve. The University of the South pacific and the NIU partners have made a good start in this connection by already committing themselves to a sustainability pathway. However, just like SD, implementation of ESD also suffers from the lack of funding, both at the global and at the regional levels. This hits the resource poor developing countries and the SIDS among them, in particular, much harder than the developed nations. This is where the Pacific 
way-a consensus approach to decision making and living together-needs to be supplemented by genuine international partnerships to create an enabling environment for ESD promotion.

\section{ACKNOWLEDGEMENT}

The generous funding support provided by ACCUUNESCO, Japan and the EDULINK initiative of European Union for the two ESD projects described in this study are acknowledged most thankfully.

\section{REFERENCES}

United Nations, 1992. Earth Summit, Agenda 21, The United Nations Programme of Action from Rio: Earth Summit. 1st Edn., United Nations, ISBN: 9211005094, pp: 294.

Eldrandaly, K.A., 2009. Integrating gene expression programming and geographic information systems for solving a multi site land use allocation problem. Am. J. Applied Sci., 6: 1021-1027. DOI: 10.3844/ajassp.2009.1021.1027

Gough, S. and W. Scott, 2007. Higher Education and Sustainable Development. 1st Edn., Routledge, U.K., ISBN: 0203938429, pp: 208.
Koshy, K. and P. Corcoran, 2010. The Pacific way: sustainability in higher education in the South Pacific Island nations. Int. J. Sustainability Higher Educ., 11: 130-140. DOI: 10.1108/14676371011031856

Koshy, K., M. Mataki and M. Lal, 2008. Sustainable development: A Pacific Island Perspective: A Report on Follow up to the Mauritius 2005 Review of the Barbados Programme of Action. 1st Edn., UNESCO, pp: 96.

Koshy, K., R. Lui and F. Tamani, 2009. Young Pacific Islanders in the Global Storm. In: Young People, Education and Sustainable Development: Exploring Principles, Perspectives and Praxis, Corcoran, P.B. and Osano, P.M. (Eds.). Wageningen Academic Publishers, ISBN: 9789086860937, pp: 207-212.

Rahman, A., J. Dbais and M. Imteaz, 2010. Sustainability of rainwater harvesting systems in multistorey residential buildings. Am. J. Eng. Applied Sci., 3: 73-82. DOI: 10.3844/ajeassp.2010.73.82

Sterling, S., 2004. Higher Education, Sustainability and the Role of Systemic Learning. In: Higher Education and the Challenge of Sustainability. Problematics, Promise and Practice, Corcoran, P.B. and A. Wals (Eds.). Springer, Netherlands, pp: 47-70. 